\title{
INSIGHTS INTO TEACHING POETRY TRANSLATION: A PLEASURABLE TASK
}

\author{
N. Berrin Aksoy*
}

\begin{abstract}
In the Translation Departments of Higher Education Institutions in Turkey as in elsewhere, poetry translation is the least studied and the most discussed course among the students who usually harbor pessimistic opinion about the possibility of going through a successful and pleasurable course. In this study, an integrated approach to the teaching of poetry translation is proposed by means of studying Philip Larkin's poem "Mr Bleaney" as the text for translation into Turkish, which is the mother tongue of the students concerned. The proposed integrated approach is an insight into the teaching of poetical translation bringing together a preliminary study of the formal, contextual and artistic elements of poetry in general and the poem as the text to be translated in particular, with that of a sound and comprehensive study of theoretical notions of poetical translation. It is hoped that this approach may prove to equip the students with the required confidence, skills, knowledge, and competencies to turn the practice of poetry translation into a pleasurable task.
\end{abstract}

Key words: poetry translation, teaching poetry translation, poetical translation

\section{Introduction}

The aim of this article is twofold: to display a classroom model consisting of several stages of teaching of poetry translation to 4 th year students of Translation at the undergraduate level in the Translation departments in Turkish Universities, and secondly, to highlight the importance of a literature-oriented approach as a prerequisite for the students to practice poetry translation into their mother tongue. It is hoped that this study may present a testimonial insight into the scope of this paper by way of drawing largely from the experience gained as a teacher of translation for more than 30 years in Turkish Universities and will provide helpful insights for the instructors elsewhere. As Killander quotes from Paran: "classroom interaction can be explored through the testimony of a practitioner reflecting on what they do in class, which can be extremely valuable" (qtd. in Killander, 2011, p. 005618). In this paper what is attempted to be discussed is ways to motivate and encourage students to practice poetical translation by strengthening their knowledge of literature and poetry in general as the basis for translation, rather than providing steps for the act of poetry translation as a classroom activity.

\footnotetext{
* Professor PhD at Atılım University, Translation and Interpretation Department, Ankara, Turkey, e-mail: berrin.aksoy@atilim.edu.tr
} 
If literary translation is regarded as the most challenging task by the students of Translation at University level, poetry translation presents students with the highest amount of challenge in terms of effort, tenaciousness and the possession of creative and appreciative faculties. Starting with the famous Robert Frost description that "poetry is what gets lost in translation" in the back of their minds, attempts to teach poetical translation becomes a major undertaking in the classroom both for the instructor and the students. In general, it may be said that at University level, teaching poetry translation is carried out by poet / translators who have accumulated teaching experience throughout the years as guest lecturers and who have great faith in the possibility of teaching poetry translation and in making it a pleasurable task for the students, and above all, in the possibility and importance of translating poetry. Similarly, apart from poet/ translators as lecturers, poetry translation can also be taught by the instructors of translation studies who have a wide knowledge, interest, and experience in poetical translation. In order to understand the artistic quality of a poem, its essence, and spirit, one does not have to be a poet himself. In order to teach poetical translation, having the necessary qualities and skills to be an instructor in the field of literary translation along with following and adopting certain methods, strategies and steps in poetical translation will open new opportunities and motivation for the students in poetry translation courses. Students must gain confidence in their knowledge and appreciation of poetry to be able to try their hands at translating it by understanding that one need not be a poet to do poetic translation; though according to Landers, the translator must possess a poetic sensitivity, even if he or she has never written a line of original poetry. For Landers, "a poetic sensitivity encompasses, but is not limited to, an appreciation for nuance, sonority, metaphor and simile, allusions, the ability to read between and above the lines; flexibility, and ultimately, humility" (2001, p. 99). This paper, then, will attempt to discuss and put forward the ways of developing such a character in the students which is actually a prerequisite to start dealing with poetry translation in a pleasurable way, hence some suggestions of how to deal with the teaching of poetry translation and how to develop this effort into a pleasurable task in the classroom will be the focus.

Teaching poetry translation and trying to instill a sense of pleasure in the students for poetry translation should start by exploring what a poem is, what it is made up of and its general and particular qualities and contextual elements. A poem is not only made up of language, that is why a purely linguistic approach to the study of poetry as a first step will not be adequate. According to the definition of poetry.org, poetry is an art form in which human language is used for its aesthetic qualities in addition to, or instead of, its notional and semantic content. It may use condensed or compressed form to convey emotion and ideas to the reader's mind or ear; it may also use stylistic devices such as assonance and repetition to achieve musical or incantatory effects. Poems 
frequently rely for their effect on imagery, word association, and the musical qualities of the language used. The interactive layering of all these effects to generate meaning is what marks poetry. Landers (2001) in his book Literary Translation quotes Random House Dictionary to define poetry as "the art of rhythmical composition, written or spoken, for exciting pleasure by beautiful imaginative, or elevated thoughts" (2001, p. 99). Hence, would-be translators of poetry must be brought to an awareness of all these qualities of a poem first and foremost. A beginning, then, in the poetry translation classroom may be to study the qualities of a poem and its stages of analysis for a thorough understanding of the text type, the poet, and the genre to be translated.

\section{Discussion}

\subsection{Preliminary studies in class}

In my experience as a Professor of Translation for more than 30 years in Turkish Universities' Translation Departments, I have come to the conclusion that teaching poetry translation course requires a multi-dimensional approach which integrates the study of literature and study of translation in theory and practice. The main reason why students are pessimistic and apprehensive to poetry translation course lies in the fact that they do not have enough knowledge and experience in the reading, studying and appreciating literature in general, and poetry in particular especially in today's globalized world where even art has become a digitalized medium of expression. Hence, a poetry translation course that starts with an exploration of the poem in a foreign language to be translated in all its contextual, formal and artistic elements may yield a more enthusiastic group of students to try to recreate that poem in their native tongue once they acquire full knowledge about the text they are going to deal with.

Preliminary studies may begin with the study of a poem, and elements of a poem as well as how to analyze them. Actually, students can be made to read several poems in their native language and foreign language belonging to certain periods and contexts. It should be noted that a poem is grounded in a social, historical, ideological and poetological context or landscape. It is of primary importance to explore this landscape and find the literary and linguistic elements that are manifest in the poem and thus, enable the students to gain an awareness of the poem in its entirety, to improve the students' literary appreciation and analysis skills as well as linguistic skills and capacity which will pave the way for them to develop an ability and to gain confidence and knowledge to deal with a poem for translation purposes. This framework is actually what it takes the students to see the whole endeavour as a pleasurable experience. To this end, in this paper, my intention is to draw attention to the importance of teaching, studying and learning poetry thoroughly as a first and foremost step in order to be able to translate in poetry translation courses. I will deal with Philip Larkin's poem 
"Mr Bleaney" for that purpose. To begin with, the students should be acquainted with the poetry as a literary genre. "What is a poem?" is the topic to be worked on in this step.

The main constituent of a poem is language and the individual use of language known as style. Language use brings the reader to the meanings and messages in the poem. For a student of translation, being able to understand and delve into the language of the original poem will enable him to interpret the meanings and to create equivalences in his native tongue. In a poem, language can do many things, it offers infinite possibilities to the poet. He can use elliptical, metaphorical, simple or ornamented language. He can go beyond the limits of language. The study of poetical language for translational purposes is very important since literary translation depends heavily on stylistic, interpretive and linguistic exercise to a great extent.

As mentioned above in this paper, the text to be studied is Philip Larkin's poem" Mr Bleaney". It may be worthwhile first to get to know the poet individually, to discuss why this poem is suitable for this paper, and to understand his language and style in this poem. The poem is:

\section{Mr Bleaney}

'This was Mr Bleaney's room. He stayed

The whole time he was at the Bodies, till

They moved him.' Flowered curtains, thin and frayed,

Fall to within five inches of the sill,

Whose window shows a strip of building land,

Tussocky, littered. 'Mr Bleaney took

My bit of garden properly in hand.'

Bed, upright chair, sixty-watt bulb, no hook

Behind the door, no room for books or bags -

'I'll take it.' So it happens that I lie

Where Mr Bleaney lay, and stub my fags

On the same saucer-souvenir, and try

Stuffing my ears with cotton-wool, to drown

The jabbering set he egged her on to buy.

I know his habits - what time he came down,

His preference for sauce to gravy, why

He kept on plugging at the four aways -

Likewise their yearly frame: the Frinton folk

Who put him up for summer holidays,

And Christmas at his sister's house in Stoke. 
But if he stood and watched the frigid wind

Tousling the clouds, lay on the fusty bed

Telling himself that this was home, and grinned,

And shivered, without shaking off the dread

That how we live measures our own nature,

And at his age having no more to show

Than one hired box should make him pretty sure

He warranted no better, I don't know.

Philip Larkin (1922-1985) is an eminent poet of post-WWII England, regarded as one of the most "English" of the poets of this period, in terms of his engagement with the contemporary English scene in his poetry, in poems such as "Whitsun Weddings", "Church Going", and "Ambulances". He did not produce too many poems but their quality was indisputable in the sense that he produced "a poetry from which even people who distrust poetry can take comfort and delight" (poetry.org). His style heavily relied on the traditional tools of poetry such as stanza, rhyme and meter "to explore the often uncomfortable or terrifying experiences thrust upon common people in the modern age" (poetryfoundation. org). Despite following traditional form, his poetry was recognized as "the most technically brilliant and resonantly beautiful, profoundly disturbing yet appealing and approachable, body of the verse of any English poet in the last 25 years" (poetryfoundation.org).

Philip Larkin enjoyed wide popularity but as a person he was shy and he rarely wanted to appear in the media or come into public light. He started writing his poems in the 1930's when the modernist poetry "began to forge more tangible links between the individuality of the speaking subject and the broader social, political and existential conditions that the speaker shared with the reader... These two factors, stylistic eclecticism and a desire to re-establish poetry as a channel between private experience and public discourse, have dominated British poetry since the late 1930' up to the present day" (Bradford, 2010, p.117). The reason for choosing Philip Larkin and his poem "Mr Bleaney" as the text to be studied as an example in this paper is his ability to create vividly realized local context that reflects the spirit of Englishness (Bradford, 2010, pp. 117-207) so powerfully.

The poem "Mr Bleaney" presents a challenge for Turkish students because of the contextual and cultural differences that surround both languages and cultures. Bradford in his book Poetry, The Ultimate Guide refers to Tom Paulin's account of (1990) Philip Larkin's poetry, and says the following: Larkin might speak for "the English male, middle-class, professional, outwardly confident, controlled and in control" and comments that "which Paulin implies is bad enough, but this demeanour marks deeper repressions and complexes. Larkin "writes with 
anxiety inside that sealed bunker which is the English ethic of privacy a collective mood of loss and failure, the end of Empire" (Bradford, 2010, p. 208).

Consequently, in the poem, "Mr Bleaney", Mr Bleaney's Englishness, with all its ambiguity and the controversies is contextually very important and its reflections must be studied thoroughly by way of studying the formal and poetical qualities of the poem by the students. For that purpose reading the poem and other poems of the same poet is recommendable. Students may be encouraged to carry out an interpretation of the cultural context of the poem among themselves and may also be asked to find similar poems and poets in their native culture and literature.

The preliminary stage of poetry translation course then may begin with the study of the formal qualities of the poem in the text itself in the classroom with the students. It may be advisable at this point that all the activities suggested in this paper should be carried out by the students themselves either in groups or individually, guided by the instructor. Manifestly, the language is simple and plain with a consistent meter and rhyme pattern along with traditionally structured stanzas in our text "Mr Bleaney".

The poem is written in 7 stanzas all of which follow a cross rhyme scheme abab, cd cd and likewise till the last stanza which goes in parallel with the regularity and commonality of lower-middle-class English life. The poem is a dramatic monologue of a simple and predictable man amid the melancholy of modern life.

The dramatic monologue is established by the references to a dialogue to give the poem a narrative style; indeed it opens with the dialogue between the speaker of the poem and his landlady who is also the landlady of the previous resident, $\mathrm{Mr}$ Bleaney. In the first stanza the language which seems plain at first unfolds the life and end of Mr Bleaney in such a nonchalant but poignant manner:

'This was Mr Bleaney's room. He stayed

The whole time he was at the Bodies, till

They moved him.'...

The use of past tense in all three lines connected with 'till they moved him' shows not only that the room is now vacated, but that Mr Bleaney died in. The use of' till 'at the end of the second line is an element of suspense, which is followed not by the good news but the announcement of the man's death. The rhyme scheme of the poem which is cross-rhymed throughout, creates the monotony and the dullness of the atmosphere Mr Bleaney and the speaker find themselves in. Hence, the students must be introduced to the importance of cross- rhyme as opposed to the adjacent rhyme particularly in this poem which points to the mood and atmosphere of the poem. The grammar used in the first 
stanza of the simple past tense announces the finality for Mr Bleaney which also hints a similarly bleak future for the narrator himself, as well.

He stayed

The whole time he was at the Bodies, till

They moved him.

The verb tenses imply the finished action yet with the implication of future validity for the narrator which requires an equivalence in the translation to create a similar message. The students should be directed to pay attention to the grammar and syntax of the lines because although at first glance the stanza seems plain, clear and simple, it embraces in itself multiplicity of meanings and ambiguities that need to be carried over through translation if one attempts to translate a Philip Larkin poem.

The poem develops like one long paragraph of a story and the state of the speaker and the miserable life of Mr Bleaney unfold as the readers eye through the poem, while simultaneously in this process, the reader witnesses that $\mathrm{Mr}$ Bleaney becomes the speaker's double and the two characters blend into one. The students must be taught to read the poem from beginning to end, not in chunks or some stanzas only. If the fluency of the narration is not captured by the students, then the metaphor, Mr Bleaney, representing all the bored little men of the $20^{\text {th }}$-century modern man is overlooked. Hence, encouraging the students first, to read the poem, from beginning to end at one go, is of primary importance.

Another basic element to be studied in class in terms of poetical language and what it stands for is the meter. The meter creates the rhythm, the rhythm creates the mood. In our poem, the meter is especially important as a poetical device but also as a tool for the creation of regularity and banality of Mr Bleaney's and his double, the speaker's life; this can be observed in the last two stanzas very clearly:

But if he stood and watched the frigid wind

Tousling the clouds, lay on the fusty bed

Telling himself that this was home, and grinned,

And shivered, without shaking off the dread

That how we live measures our own nature,

And at his age having no more to show

Than one hired box should make him pretty sure

He warranted no better, I don't know. 
The meter is a ten-syllable scheme with cross rhymes. The stress on the syllables is also an important constituent. Here, it may be worthwhile to work on some native poems with similar meter and rhyme schemes for the students to better grasp their function. For that purpose, a poem by Turkish poet Cahit S1tk1 Taranc1, who is regarded as the poet of meter and rhyme in modern Turkish poetry can be studied. The following poem may be an example for that purpose:

Memleket

Bir yanda Anadolu bir yanda Rumeli'dir

Hepsi bizden yolcusu olsun hancisı olsun

Efkar ettiğimiz şey memleket halidir

Sanmam hemşerim sanmam bundan acısı olsun

Köylümüz efendimiz tarlasında perişan

İşçimiz kardeşimiz kavgasında perişan

Anam bacımdır bahtı karasında perişan

Hemen Allah cümlemizin yardımcısı olsun (1947)

The poem is written in 13-14 syllables with cross rhyme scheme similar to $\mathrm{Mr}$ Bleaney pattern. The similarity and the function of the stress on the syllables such as 'ol-sun' (ol-strong, sun weak) in the Turkish case and 'I don't know' (I strong don't strong, know weak) in the English case should also be worked on and their function to create rhythm to arrive at a meaning should be highlighted. The point in studying a similar structure is to make students aware of the existence of similar patterns in both literary traditions and hence, motivate their trust in the capacity of their own poetic tradition in order to allow the creation of the translation of an English poem into Turkish.

After dwelling on the meter, rhyme and structure of the English poem "Mr Bleaney", and drawing parallels with native Turkish poetry of the same period, the main body of the poem, that is, its vocabulary, syntax and the effects created by these elements must be studied and identified in the classroom in order to help students to recreate these usages in Turkish.

The title of the poem "Mr Bleaney" is also the name of the previous resident of the room the speaker is going to take. From the preliminary reading of the poem, the mood and atmosphere along with the exploration of these elements by the students through the guidance of the instructor have already at this stage, installed in the students a notion that the poem is told in an atmosphere of bleakness, dullness, and mediocrity which is related to the context the poem belongs to and to the style of the poet. The title and the name also suggest the same spirit. This is an important point in this poem since the gist of the poem seems to be unfolded in the title, which is also the first word of the poem. This poetical device which is called irony as a stylistic element should be well 
explained by drawing parallels with another Cahit Sitk1 Tarancı poem named "Abbas". Abbas is a Turkish name and the person the speaker is talking to in the poem. He is not only the addressee, the name Abbas represents commonality and ordinariness in its literal meaning. This double meaning and irony of the title posit itself on the same level as the implied meanings of Mr Bleaney and the bleakness of the poem. Thus, studying another parallel stylistic device in Turkish will be an added bonus for the students in their initiation into the attempts of translating "Mr Bleaney".

Another important quality of "Mr Bleaney" is the use of "commonplace and lackluster' (Bradford, 2010, p.207) vocabulary in harmony with the life of Bleaney and the speaker as created by the poetic devices. The word choice such as

'Flowered curtains, thin and frayed,

Fall to within five inches of the sill,

Whose window shows a strip of building land,...

Bed, upright chair, sixty-watt bulb, no hook

Behind the door,...

Stub my fags

On the same saucer-souvenir,

I know his habits---

His preference for sauce to gravy,

And Christmas at his sister's house in Stoke.

There is no inspirational vocabulary in the description of the room and the occupant's lifestyle, no cheerful word or sounds to mark a joyous tone. What is more, the 6th stanza is filled with assonance and alliterations that create the onomatopoetic sound of the wind described as the "frigid wind" in the first line of the 6th stanza. The importance of studying literary devices and figures of speech in theory and practice is a must for the students of translation in poetry translation courses. Studying these elements in this poem and a similar one in Turkish, such as Nazım Hikmet's famous poem "Salkımsöğüt", where the vocabulary and the onomatopoeic quality of the word choice along with its receding rhythm create the lamentable and sorrowful incident as described in the poem, may provide the students with a sound example of how these devices are created by the power of the Turkish language.

The poem "Mr Bleaney"s syntax is composed in such a manner that it resembles reading a journal kept by the speaker of the poem. The first three stanzas are an account of the minute details of the room Mr Bleaney vacated, very plain but slightly ambiguous in examples such as: 
This was Mr Bleaney's room. He stayed

The whole time he was at the Bodies, till

They moved him'. Flowered curtains, thin and frayed,

Fall to within five inches of the sill,

The students must be led to explore the significance of the syntax, and the kind of stylistic devices used throughout the poem within the syntactic organization. It should be noted that the syntax serves to the purpose of building a sense of place in the poem. The ambiguity of the seemingly simple and plain syntax gives us the clues about characters which must be studied by studying the vocabulary units with their connotations such as "thin and frayed", "a strip of building land", "bit of garden", "upright chair", "frigid wind" etc. all pointing out to the bleak life of both men.

The last stanza is especially important since in this last part the poet delves into generalizations and philosophizes about life. The form and the structure of the last stanza should be highlighted by the instructor as one long sentence in a dramatic monologue on thoughts about how we evaluate ourselves, our worth by the way we live. The last line that ends with 'I don't know' is the climax of the poem, which is situated at the end, not in the middle as one would expect in a traditional form.

The double meaning of 'I don't know' utterance, and its connection to the beginning of the stanza 'That how we live measures our own nature' bring us to the speaker himself, not Mr Bleaney; the speaker does not know how $\mathrm{Mr}$ Bleaney evaluates himself, he cannot be sure of that; but he knows his own worth, he knows how he himself lives.

Students' active work on the form and meaning of the poem makes them appreciate the poem and the poet's style in a more informed way which will undoubtedly pave the way for them to take pleasure from this experience. Richard Bradford's remark about Larkin's style and the relationship between form and meaning of the poem "Mr Bleaney" is highly relevant at this point: "aside from such involuntary functions as breathing, everything we encounter causes us to judge it" (Bradford, 2010, p. 228). The text itself, the poem, is the object to be translated; the students as active readers and interpreters of the poem "react to the poems based on their own experiences, emotions and ideas" (Khatib, 2011, p. 168). Only then, the students can feel capable enough to try their hands at the translation of that poem and see this act as a pleasurable effort. Also, encouraging the students to find and study similar poems in their native language and literature will foster in the students a sense of what a poem is, so as to be able to create 'a poem' in a language other than the language of the original poem. 


\subsection{Theoretical Background}

The second stage of teaching poetry translation to the students of Translation departments must involve theoretical investigation. There are various opinions on whether studying translation theory is necessary to translate well or not. Many practicing translators claim that although they have no knowledge of a translation theory or hold no degree in translation, yet, they are capable of translating literature adequately and gain recognition for their translations. They may be right in their own context, especially if they belong to an older generation of translators when translation was not established as a field of academic study but regarded as a branch of linguistic and literary study and practice. On the other hand, the evolution of translation as a separate and multi-disciplinary academic field especially with the cultural turn in the 1980s followed by an increase in the research and theorizing of translation along with the opening of Translation degree programmes in the higher education institutions created a need and a scientific structure for the study and practice of translation. Hence, students need to study both aspects of translation since, in the first place, an academic study on a higher education level requires the teaching and the acquisition of the scientific and theoretical background of the degree to be earned. Secondly, studying the theoretical aspect of translation gives students an insight of the accumulated experience and formulations of the translation profession and equip the students with the knowledge, skills, and competencies to deal with the challenges of the practice and profession of translation. As Pym writes in his book Exploring Translation Theories (2014):

awareness of different theories might be of practical benefit when confronting problems for which there are no established solutions, where significant creativity is required. The theories can pose productive questions and sometimes suggest novel answers. .... Awareness of a range of theories might also help the translation profession in a more direct way. Unfortunately, our educational institutions tend to separate theory from practice, often demanding a separate course in 'translation theory'. If necessary, that can be done. However, the theories and their implications should still be drawn out from a series of practical tasks, structured as discovery processes. (pp. 4-5)

In this study, as mentioned earlier, an integrated approach to the teaching of poetry translation in the poetry translation courses coincides with what Prof Pym is talking about. In the classroom studies, students must also be introduced to the theoretical aspects of poetry translation and literature produced by the scholars and poets themselves on this topic. This way, students will have a firm ground in their attempts at translating a poem and will feel more confident about their selections and choices and about their methods of translation during the translation process in class. It may be worthwhile to mention here 
that Translation theory as a separate course which introduces the students to a body of comprehensive theories of translation is given to the students earlier in their 3rd year. However, that course does not primarily comprise theories and methods of poetry translation as its focus.

This second stage of poetic translation course then may comprise a selection of scholarly articles and books on poetry translation which contain valuable information on the procedures and methods of poetry translation. James S. Holmes, André Lefevere, Susan Bassnett are some of the most distinguished scholars and theoreticians in this field, who have contributed greatly to the establishment of Translation Studies as an academic field of study and research. Theoretical study of poetry translation can be taken up after the Preliminary Study and it would be a good idea to ask the students to read these scholars and to discuss their suggestions in class now that they have developed a built-in notion of how to approach a poem for translational purposes. A comparative study of André Lefevere's seven strategies for poetry translation with those of James Holmes' form-derivative, content-derivative approach to poetry translation can engage the studies in a more enjoyable and down-to-earth way to the act of translation by practising all these approaches on the text, which is the poem, chosen for translation in class.

\section{Conclusion}

To conclude, the preliminary study and theoretical study discussed above in this paper taking as its core Turkish students in the departments of Translation in Turkish universities propose an integrated approach which brings together teaching and exploring in class literary, artistic and aesthetic qualities of the poem together with the teaching and practicing of related translational theories, methods and approaches in the teaching of poetry translation course. Depending on the cultural and linguistic contexts of different countries and their approach to poetry translation, this integrated model may be adopted and adjusted to the needs of particular students and degree programmes. One thing seems to be certain though, for all the students of poetry translation classes everywhere, which is, as Landers says, "anyone who can't read an (English) -language poem with feeling and more than surface comprehension is an unlikely candidate for poetic translation" (2001, p. 99).

\section{References:}

Bradford, R. (2010). Poetry, the ultimate guide. Palgrave Macmillan. St Martin's Press LLC, New York.

Khatib, M. (2011). A new approach to teaching English poetry to EFL students. Journal of Language Teaching and Research, 2.1, 164-169. 
Killander, C. C. (2011). Poetry in foreign language teaching: Aspects of a major challenge. In Proceedings of the International Conference of Education, Research and Innovation (ICERI), (pp. 005618-005626). Madrid, 14-16 November 2011.

Landers, C. (2001). Literary Translation. A practical guide multilingual matters. LTD. Clevedon.

Pym, A. (2014). Exploring Translation Theories. Routledge, London and New York.

Tarancı, C. S. (1991). Memleket. In M. F. Adam (Ed.), Çagdaş Türk şiiri antolojisi. İstanbul.

"Philip Larkin". 22.06.2018. Retrieved from www.poetryfoundation.org

"What is poetry". 21.06.2018. Retrieved from http://www.poetry.org/whatis.htm 